Article

\title{
Analysis of Selected Building Constructions Used in Industrial Construction in Terms of Sustainability Benefits
}

\author{
Jozef Švajlenka ${ }^{1, *(D)}$, Mária Kozlovská ${ }^{1}$ and Terézia Pošiváková $^{2}$ (D) \\ 1 Department of Construction Technology and Management, Faculty of Civil Engineering, \\ Technical University of Košice, Vysokoškolská 4, 04200 Košice, Slovakia; maria.kozlovska@tuke.sk \\ 2 Department of the Environment, Veterinary Legislation and Economy, \\ University of Veterinary Medicine and Pharmacy of Košice, Komenského 73, 04181 Košice, \\ Slovakia; terezia.posivakova@uvlf.sk \\ * Correspondence: jozef.svajlenka@tuke.sk or ingsvajl@gmail.com; Tel.: +421-55-602-4381
}

Received: 11 October 2018; Accepted: 21 November 2018; Published: 24 November 2018

\begin{abstract}
Enormous development of technology over the past two centuries has been associated with a considerable drawdown of non-renewable raw materials and an increase in the amount of harmful emissions. Thus, building direction in the field of construction implies a significant implementation of sustainability. The preference for environmentally friendly technology solutions is the right way to meet the sustainability trend. The main aim of this study was to analyze and verify selected construction systems of buildings designed for agricultural primary production in terms of their environmental impacts. The supporting construction systems of the comparative design variants was designed from a variety of material bases (concrete, steel, and wood). To evaluate environmental construction systems, the LCA methodology in mode "Cradle to Gate" was used. Parameters of sustainability related to the environmental impact were analyzed. These results could be a useful tool for the evaluation and comparison to an appropriate choice of the design option for an industrial building designed for agricultural primary production in terms of environmental impact.
\end{abstract}

Keywords: agricultural construction; Cradle to Gate; environmental parameters; industrial buildings; life cycle assessment; sustainability; transport

\section{Introduction}

The interest in sustainable development in the last forty years has shaped our current sustainability approaches, such as the definition of sustainable development, i.e. development that satisfies the needs of the present without affecting the ability of the generations to come to satisfy their own needs $[1,2]$.

Sustainability consists of economic, environmental and social factors and their relations [3]. Social priorities involve a growing global consensus on which we should protect and improve animal welfare [4].

Sustainable agriculture is agriculture that satisfies the needs of the present without affecting the ability of the generations to come to satisfy their own needs [5]. Sustainability has become a central concept partly due to the apparent need to produce sufficient food for the ever-growing world population and to simultaneously preserve the environment and contain climate change $[6,7]$. Therefore, the focus has been on food production, environmental services and social goods, although we also need to consider their consumption, along with other factors, e.g. losses and waste generated during production, sale and distribution [8-10].

Sustainable intensification is understood as increasing the volume of production, while concurrently improving efficiency in the use of inputs and reducing harmful impact of food production 
on the environment [11]. Social and economic changes are needed to understand what outputs are required of those involved in food production, along with new research to deal with objectives which are more complex than simply achieving larger production volumes [12].

Agriculture and its various fields have undergone numerous transformations and developments, improving its quality. Rural areas and areas outside city centers (peripheries), which have been neglected up until recently, are now gaining in importance [13]. It is mainly these areas' significance in terms of ecology and sustainability that is growing-they are significant as a place where the environment's natural elements exist and recover, acting as a basic precondition of preserving human health, including healthy and quality food and nourishment. Food production is an important social factor that is crucial for human survival, so its qualitative aspect is a key determinant of living standards, and is also important in terms of sustainability [14,15].

At present, the emphasis is put on the development of environmentally friendly technologies. It is not only about energy-saving technologies, but also an overall approach that aims to minimize any undesirable environmental impacts of plant operation, or the production and use of products themselves [16]. It is important to always choose a technology that is more environmentally friendly, and to consider all its consequences [17]. The incentives for experts to start dealing with eco-vacancy are mainly population growth, limited fossil stock and rising environmental pollution [18]. The aim is to optimize their parameters to minimize the burden on the environment, in particular with regard to resource use; production, transport and distribution; consumption; and end-of-life disposal $[19,20]$.

The most important aspect in assessing environmental impacts is energy consumption [21-23], which is related to a limited amount of energy sources as well as accompanying negative phenomena such as atmospheric emissions contributing to acid rain, smog and greenhouse effect (Embodied energy (EE), Global warming potential (GWP) and Acidification potential (AP)) [24,25]. In particular, the greenhouse effect is most likely the most serious of the current environmental impact at all [26].

Currently, the Life Cycle Assessment (LCA) analysis method is applied worldwide. The LCA method has a fixed structure and is performed according to the international standards of the ISO 14040 series. Commercially available process databases and material and energy flows are used to efficiently process LCA studies $[27,28]$. It is one of the most important information tools for environmentally oriented product policy. The LCA can be defined as collecting and evaluating inputs, outputs and possible environmental impacts of the product system throughout the life cycle [29]. According to ISO 14040 and 14044, life cycle assessment is performed in four different phases.

Based on the above-mentioned selected aspects of sustainability in the context of the agricultural sector, we set the following goal and the direction of our research. The subject of the study of our work was the most frequently used construction systems of agricultural buildings considered in terms of selected aspects of sustainability. In the course of our work, we focused on the evaluation of the cradle-to-gate variant. "From Cradle to Gate" is the assessment of the partial life cycle of a product from the extraction of raw materials ("cradle") to the factory (exit) gate (i.e., before it is transported to the consumer) [30]. The use and disposal phases of the product are omitted in this case. Cradle-to-gate evaluations are sometimes the basis for environmental product statement (s). In particular, the following aspects were considered in the evaluation: EE, GWP and AP. In addition, our work was complemented by an analysis of the transport of building materials from manufacturers to the construction site in terms of greenhouse gas production and emissions.

\section{Methodology of Research}

The research object was real buildings designed for agricultural primary production (livestock farming). The paper presents analysis of the environmental advantages of a modern prefabricated wooden panel construction with traditional building systems based on prefabricated reinforced concrete components and a steel structural system through the above parameters. To evaluate the sustainability of the compared construction systems, a part of the LCA was implemented within 
the set boundaries of the assessment. The LCA analysis was further extended by assessing the $\mathrm{CO}_{2}$ production during transport of the fixed components and materials needed for construction.

\subsection{Research Subject}

The subject of the research was selected structural systems of industrial buildings used mainly as agricultural objects in the V4 countries (Czech Republic, Slovak Republic, Poland, and Hungary-Central Europe) [31]. Examined and compared construction systems were designed on the basis of different construction materials (concrete, steel, and wood). All of the construction variants being compared were implemented by so-called fly-by-assembly (based on similar assembly principles with a different material basis). In addition, the compared objects had a comparable capacity of objects in terms of the built-up area and the obsolete space (Table 1), while maintaining the comparable thermal and technical properties of the structure.

Table 1. Structural characteristics of construction systems.

\begin{tabular}{ccccccc}
\hline Type & \multicolumn{2}{c}{ 1 Module } & \multicolumn{3}{c}{ All Construction } \\
\hline & Size & Built-Up Area $\left.\mathbf{( m}^{\mathbf{2}}\right)$ & Built-In Space $\left.\mathbf{( m}^{\mathbf{3}}\right)$ & Size & Built-Up Area $\left.\mathbf{( m}^{\mathbf{2}}\right)$ & Built-In Space $\left.\mathbf{( m}^{\mathbf{3}}\right)$ \\
\hline C1a & $6 \times 12$ & 72 & 324.54 & $12 \times 72$ & 864 & 3894.48 \\
\hline C1b & $6 \times 12$ & 72 & 295.20 & $12 \times 72$ & 864 & 3542.40 \\
\hline S1a & $6 \times 12$ & 72 & 303.36 & $12 \times 72$ & 864 & 3640.32 \\
\hline S1b & $6 \times 12$ & 72 & 295.74 & $12 \times 72$ & 864 & 3548.88 \\
\hline W1a & $6 \times 12$ & 72 & 293.88 & $12 \times 72$ & 864 & 3526.56 \\
\hline W1b & $6 \times 12$ & 72 & 252.00 & $12 \times 72$ & 864 & 3024.00 \\
\hline
\end{tabular}

\subsection{Methodology of Environmental Parameters Assessment}

The environmental evaluation of construction systems was made by LCA methodology in mode "Cradle-to-Gate". The materials were investigated in three constructions groups: foundation, superstructure and roofing. Considered building materials and structures are shown and specified in the notes below (Figures 1-6). The composition of floor structures was the same for all variants (iron-concrete slab, $145 \mathrm{~mm}$; waterproofing, $5 \mathrm{~mm}$; underlying concrete, $100 \mathrm{~mm}$; compacted gravel-sand bedding, $100 \mathrm{~mm}$ ).

The environmental characteristics of the EE, GWP and AP of analyzed structural systems or their respective materials were evaluated by the basic characteristics of the IBO database (Austrian Institute for Healthy and Ecological Building (IBO) Passivhaus-Bauteilkatalog) [32]. The aforementioned environmental aspects were determined according to Equations (1)-(3).

$$
E E=\sum_{i=1}^{n} E E_{i} \times w_{i} \quad[\mathrm{MJ}]
$$

where:

$E E$ is embodied energy

$E E_{i}$ is coefficient of embodied energy for $i$ th material $\left[\mathrm{MJ} \cdot \mathrm{kg}^{-1}\right]$

$w_{i}$ is weight of $i$ th material $[\mathrm{kg}]$

$$
G W P=\sum_{i=1}^{n} E \mathrm{CO}_{2_{i}} \times w_{i} \quad\left[\mathrm{kgCO}_{2 \mathrm{eq}}\right]
$$

where

GWP is global warming potential

$E \mathrm{CO}_{2_{i}}$ is coefficient of carbon dioxide equivalent for $i$ th material $\left[\mathrm{kgCO} \mathrm{eq}_{2} \cdot \mathrm{kg}^{-1}\right]$

$w_{i}$ is weight of $i$ th material $[\mathrm{kg}]$ 


$$
A P=\sum_{i=1}^{n} E S O_{2_{i}} \times w_{i} \quad\left[\mathrm{kgSO}_{2 \mathrm{eq}}\right]
$$

where

$A P$ is acidification potential

$\mathrm{ESO}_{2}$ is coefficient of sulphur dioxide equivalent for $i$ th material $\left[\mathrm{kgSO}_{2 \mathrm{eq}} \cdot \mathrm{kg}^{-1}\right]$

$w_{i}$ is weight of $i$ th material $[\mathrm{kg}]$

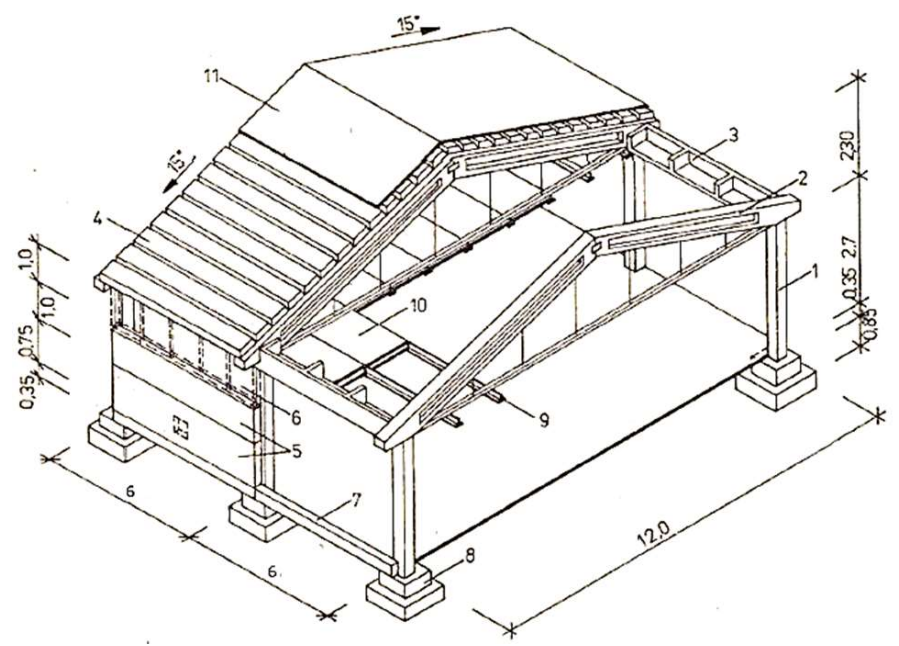

Figure 1. Structural and materials characteristics of construction system C1a [31]. Note: 1, column $0.3 \mathrm{~m} \times 0.3 \mathrm{~m} ; 2$, three-armed beams with steel rod; 3, ribbing wreath; 4 , roof rack plate SZD; 5 , peripheral sandwich panel rough $0.2 \mathrm{~m} ; 6$, window belt; 7 , base reinforcement $0.2 \mathrm{~m} \times 0.35 \mathrm{~m}$; 8 , prefabricated foundation foot; 9 , beam ceiling (wood T profile); 10 , ceiling panel (thickness $0.1 \mathrm{~m}$ ); 11 , covering (fiber-cement boards).

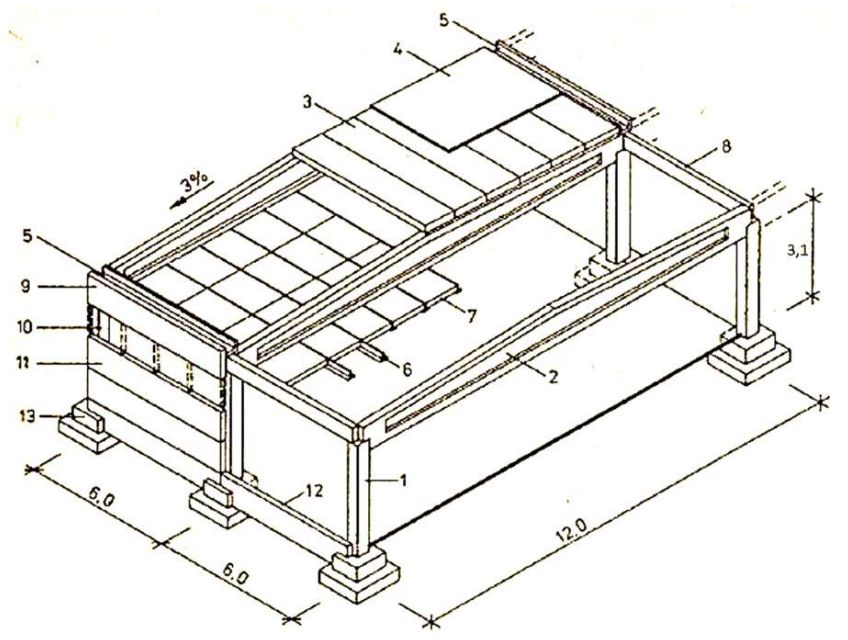

Figure 2. Structural and materials characteristics of construction system C1b [31]. Note: 1, column $0.6 \mathrm{~m} \times 0.3 \mathrm{~m} ; 2$, prestressed girders; 3, roof panel (width $1.2 \mathrm{~m}$ ); 4, asphalt cover on the leveling cement screed; 5 , gutter element (width $0.6 \mathrm{~m}$ ); 6 , beam ceiling; 7 , thermal insulating ceiling panel; 8 , longitudinal stiffener $0.3 \mathrm{~m} \times 0.6 \mathrm{~m}$; 9 , attic panel; 10 , window belt; 11 , wall iron-concrete panel (width $0.25 \mathrm{~m}$ ); 12 , plinth beam $0.25 \mathrm{~m} \times 0.6 \mathrm{~m} ; 13$, prefabricated foundation foot. 


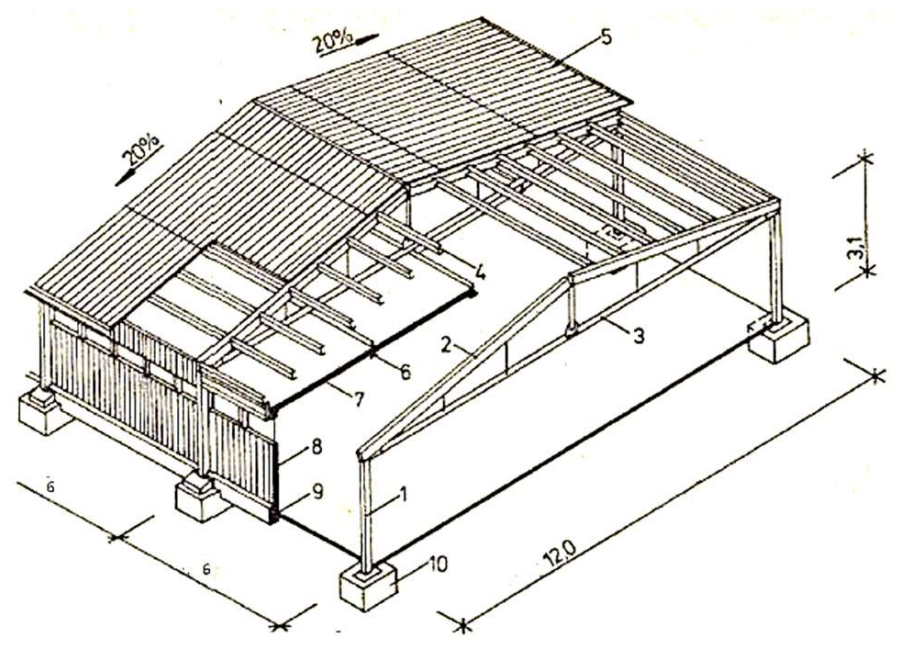

Figure 3. Structural and materials characteristics of construction system S1a [31]. Note: 1, column of rectangular cross-section welded from thin-walled profiles $\mathrm{U} 162 \mathrm{~mm} \times 55 \mathrm{~mm} \times 4 \mathrm{~mm}$; 2, beam of rectangular cross-section welded from two thin-walled profiles $\mathrm{U} 210 \mathrm{~mm} \times 50 \mathrm{~mm} \times 4 \mathrm{~mm}$ with attachments $90 \mathrm{~mm} \times 14 \mathrm{~mm}$ on the flanges; 3 , rod $95 \mathrm{~mm} \times 4 \mathrm{~mm}$; , beam of thin-walled profile $\mathrm{U}$ $162 \mathrm{~mm} \times 55 \mathrm{~mm} \times 4 \mathrm{~mm}$; , covering of profiled aluminum sheet KOB $1004 \times 0.8 ; 6$, beam support welded from two profiles $\mathrm{L} 80 \mathrm{~mm} \times 50 \mathrm{~mm} \times 6 \mathrm{~mm}$; thermal insulation ceiling panel made up of aluminum profiled sheets KOB 1004 and mineral wool mats of thickness $80 \mathrm{~mm}$ (embedded in a plastic film); 8, wall thermal insulating panel (thickness $90 \mathrm{~mm}$ ) (panel cover with aluminum profiled sheet); 9 , reinforced concrete prefabricated element; 10, prefabricated foundation foot with anchor hooks.

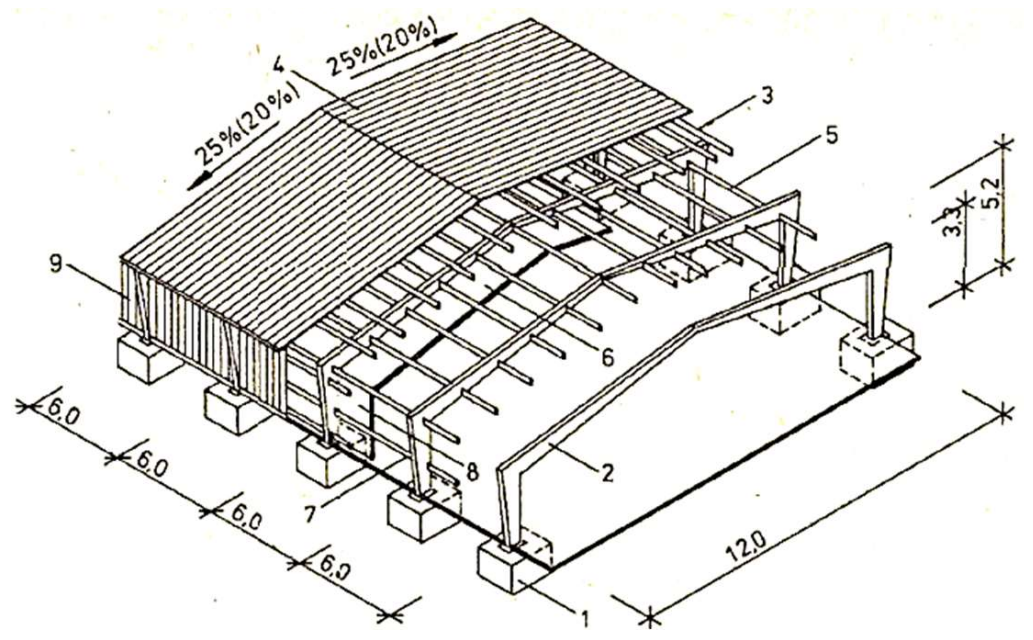

Figure 4. Structural and materials characteristics of construction system S1b [31]. Note: 1, prefabricated foundation foot with anchor holes; 2 , steel frame of closed variable cross-section; 3 , beams of rolled profile; 4 , covering of profiled aluminum sheet; 5 , ceiling beams of rolled sections; 6 , ceiling panels are covered with profiled aluminum sheet with thermal insulation from mineral wool; 7 , beams of rolled profiles; 8 , wall panel (composition as in ceiling); 9 , external cladding of profiled aluminum sheets. 


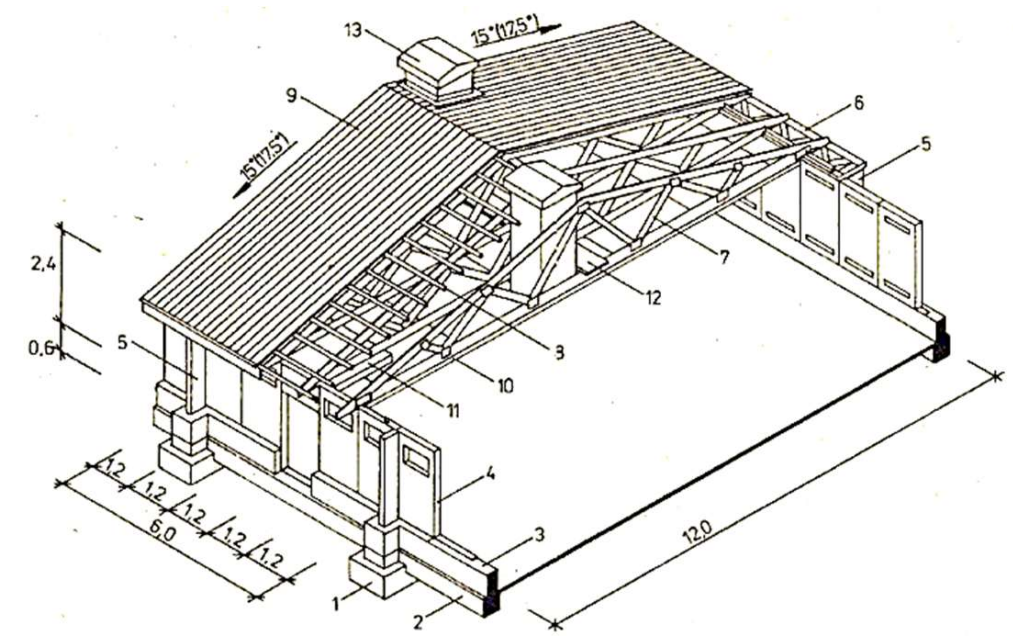

Figure 5. Structural and materials characteristics of construction system W1a [31]. Note: 1, prefabricated foundation foot; 2 , prefabricated base portion; 3 , masonry with thermal insulation; 4 , a load-bearing peripheral panel with thermal insulation and necessary installation transitions; 5 , reinforcing pillars; 6 , outer beam; 7, beam girder with joint plates Gang-Nail; 8, battens; 9, covering of profiled aluminum sheet 10 , ceiling thermal insulating panel.

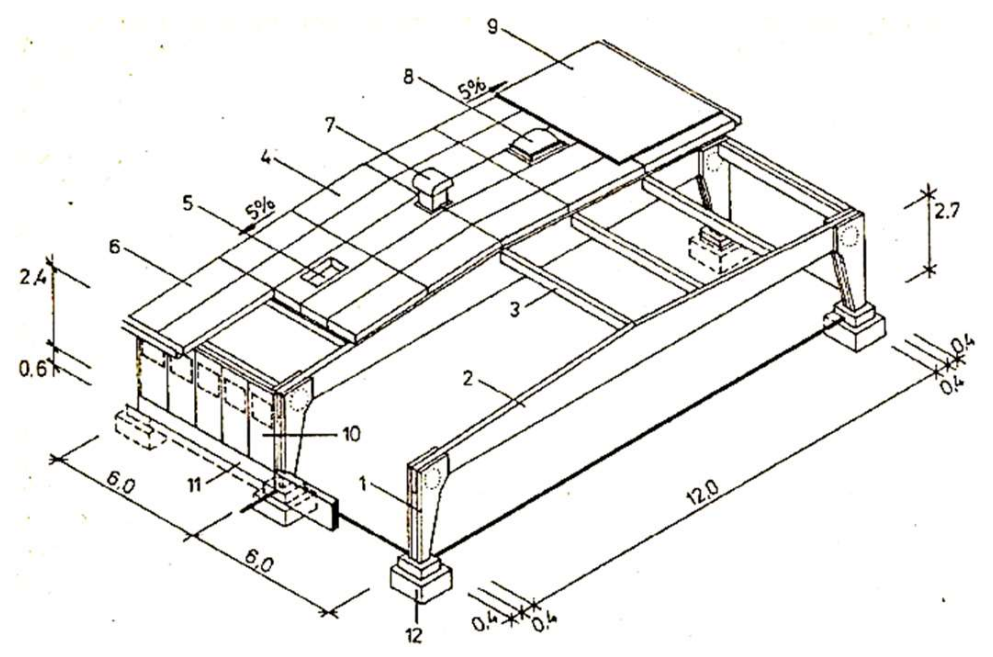

Figure 6. Structural and materials characteristics of construction system W1b [31]. Note: 1, column; 2, glued cross members; 3, glued beams $180 \mathrm{~mm} \times 360 \mathrm{~mm}$; , supporting roof thermal insulating panel with a ventilated cavity $3000 \mathrm{~mm} \times 1200 \mathrm{~mm} \times 270 \mathrm{~mm} ; 5$, roof panel with hole for skylight installation; 6, roof thermal insulating panel-gutter $4000 \mathrm{~mm} \times 1200 \mathrm{~mm} \times 270 \mathrm{~mm}$ with inlet vents to the roof; 7 , double skylight; 8 , ventilating attachment; 9 , multilayer asphalt roofing; 10 , wall thermal insulating panel $1200 \mathrm{~mm} \times 3000 \mathrm{~mm} \times 100 \mathrm{~mm}$; 11, masonry; 12, prefabricated foundation foot with anchor holes.

In the context of sustainability, realization of construction works raises the question of further transporting the necessary materials and products on site, which is the main producer of $\mathrm{CO}_{2}$ emission. The environmental aspect of the assessment was therefore extended to include the impact of the transport of construction materials and products used in the construction of the assessed variants from production to the construction site. The analysis of transport processes of both variants focused on the number of rides (NR) (Formula (4)) which related to the total weight and volume weight of products and materials, but especially to the production of $\mathrm{CO}_{2}$ emissions. $\mathrm{CO}_{2}$ emissions $\left(E_{\mathrm{CO}_{2}}\right)$ generated from the transport of construction materials from the gate of material producer to gate of building site and its value depended on number of rides, transport distances and average value of $\mathrm{CO}_{2}$ emissions of transport vehicles (Formula (5)). The weight of the material transported was closely related to the 
number of drives of the mechanisms. An average useful vehicle load capacity of 20 ton (with respect to acceptable load of roads in region V4) was regarded in calculation. For analysis, an average quantity of the emissions of $0.8 \mathrm{~kg} / \mathrm{km}$ was considered. Various distances were examined in the transport analysis, assuming an average fuel consumption of $30 \mathrm{~L}$ per $100 \mathrm{~km}$.

$$
N R=\sum_{\substack{n \\ k=1}}^{l} \cdot \frac{w_{i}}{t c_{k}}
$$

where

$N R$ is number of rides

$w_{i}$ is weight of $i$ th material $[\mathrm{kg}]$

$t c_{k}$ is transport capacity of $k$ th transport vehicle $[\mathrm{kg}]$

$$
E_{\mathrm{CO}_{2}}=\sum_{i=1}^{n} N R_{i} \times d_{i} \times \bar{x}_{\mathrm{CO}_{2_{k}}} \quad[\mathrm{~kg}]
$$

where

$E_{\mathrm{CO}_{2}}$ is $\mathrm{CO}_{2}$ emissions

$N R_{i}$ is number of rides for $i$ th material [-]

$d_{i}$ is transport distances for $i$ th material $[\mathrm{km}]$

$\bar{x}_{\mathrm{CO}_{2}}$ is average value of $\mathrm{CO}_{2}$ emissions for $k$ th transport vehicles $\left[\mathrm{kg} \cdot \mathrm{km}^{-1}\right]$

\subsection{Specification of Research Entities}

The experimental objectwas the construction of farm buildings designed for cattle breeding. To compare expected advantages of a modern wooden system, alternatives to the building based on the traditional building system of precast concrete and steel construction were also compared.

In the calculations of selected variants, the basic requirements placed on the construction systems were considered:

- the span of a module structure according to the applicable regulatory requirements;

- $\quad$ assembly method of construction;

- $\quad$ resistance to settling environment;

- fire resistance according to valid legal regulations;

- $\quad$ resistance to mechanical damage; and

- $\quad$ easy maintenance, cleaning and disinfection.

Reinforced concrete structures have considerable resistance to aggressive environments, mechanical damage and low maintenance. Steel full-body structures have a smaller weight than concrete and more variability, but these structures place great emphasis on perfect anti-corrosion protection and the need for frequent maintenance. Modern wood-glued solid structures are resistant to aggressive environments, are quickly assembled and provide great variability.

\subsubsection{Reinforced Concrete Construction System C1a}

Vertical support structure consists of columns attached to monolithic or prefabricated feet. The pillars are prefabricated with pockets for the storage of bundles, which are assembled from two pieces connected by a steel rod. The construction span is $12 \mathrm{~m}$, the longitudinal module is $6 \mathrm{~m}$. The construction height to the bottom edge of the bar is $3.15 \mathrm{~m}$. Perimeter tents are made of sandwich panels (concrete-thermal insulation-concrete).

\subsubsection{Reinforced Concrete Construction System C1b}

In this single-story construction system, the support pillars are attached to the base. Pre-filled, full-length jaws are hinged on pillars. Other structural elements include base sills, corrugated roof 
trusses, roof panels and gutter beams. Construction span is $12 \mathrm{~m}$ with $6 \mathrm{~m}$ longitudinal module. The height for the housing is $3.9 \mathrm{~m}$. The wall casing is made up of prefabricated sandwich panels.

\subsubsection{Steel Construction System S1a}

The construction system is in the transverse direction formed by loose columns with a hinged jaw. The construction is a three-armed, rigid drawbar with hinges. Columns and pillars are welded from thin-walled profiles. Construction span is $12 \mathrm{~m}$ with $6 \mathrm{~m}$ longitudinal module. The height of the hall is $3.6 \mathrm{~m}$. The wall casing is made up of prefabricated sandwich panels with aluminum sheet covering.

\subsubsection{Steel Construction System S1b}

The supporting structure consists of a welded three-armed frame of unequal box cross section. Frame stands are hinged on concrete feet. Construction span is $12 \mathrm{~m}$ with $6 \mathrm{~m}$ longitudinal module.

\subsubsection{Construction System Based on Wood W1a}

The supporting peripheral tents consist of thermal-insulating sandwich panels, on which roof trusses are laid. The nodes are connected system Gang-Nail. The stability of the object is secured in the transverse direction by the $6 \mathrm{~m}$-long snap-hooks, lined with bases and horizontal longitudinal beams. The layout of the structure is $12 \mathrm{~m}$ with a $6 \mathrm{~m}$ transverse module.

\subsubsection{Construction System Based on Wood W1b}

The main elements are full-faced glued, circumferential glued wooden pillars. The end stand is connected to the transverse (a two-armed frame is created). Intersections are embedded in construction at an axial distance of $3 \mathrm{~m}$. The object's extension is $12 \mathrm{~m}$ with a $6 \mathrm{~m}$ transverse module. The height of the building is $4.8 \mathrm{~m}$. The wall casing is made of thermal insulating sandwich panels.

\section{Results}

In the context of sustainability, the underlying environmental characteristics within the defined boundaries were assessed. For better clarity, the analysis was selected according to the main technological stages (foundations, superstructure, and roofing) (Figures 7-12). In addition, the individual variants were evaluated as a whole but also as part of the structure, Module 1, without a front (Figures 7-9).

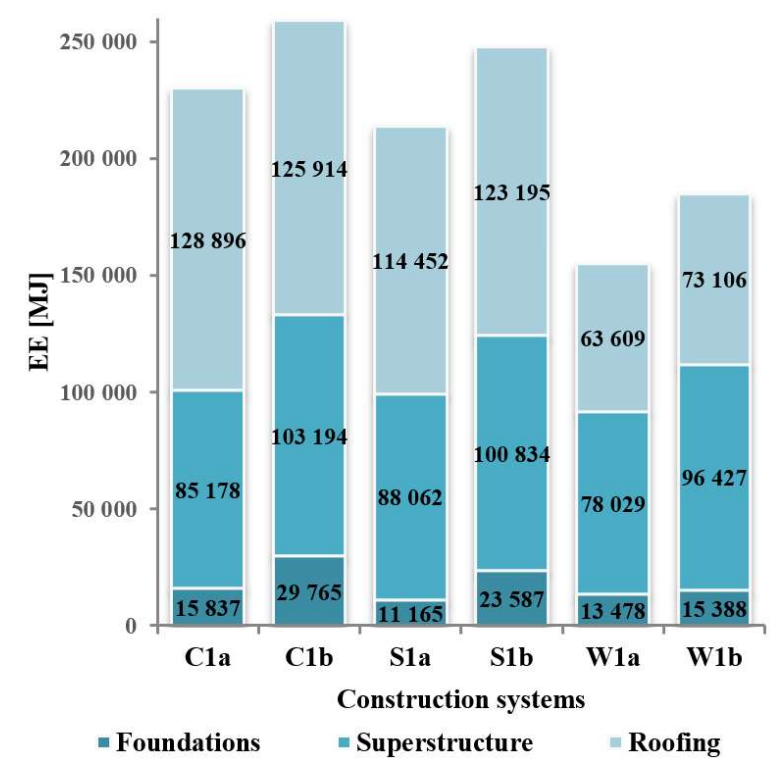

Figure 7. Module 1: Analysis of EE. 


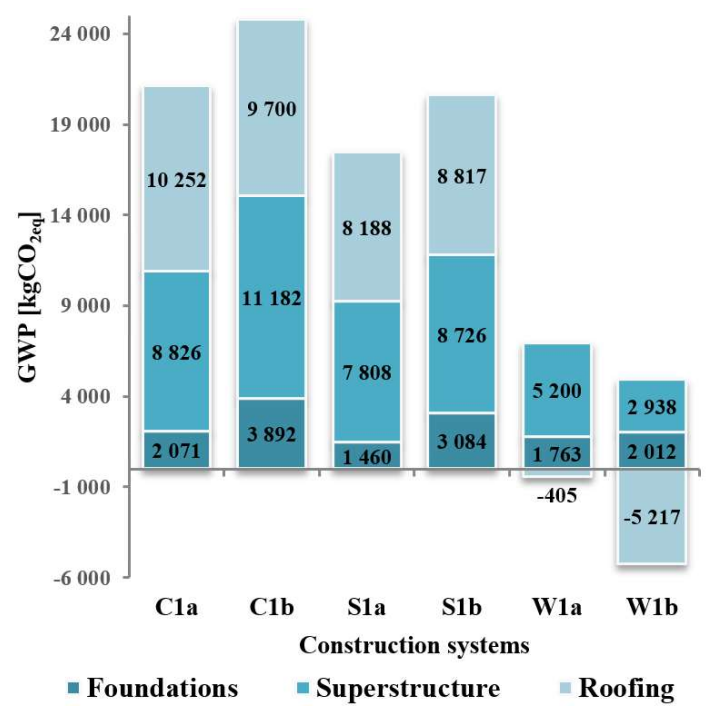

Figure 8. Module 1: Analysis of GWP.

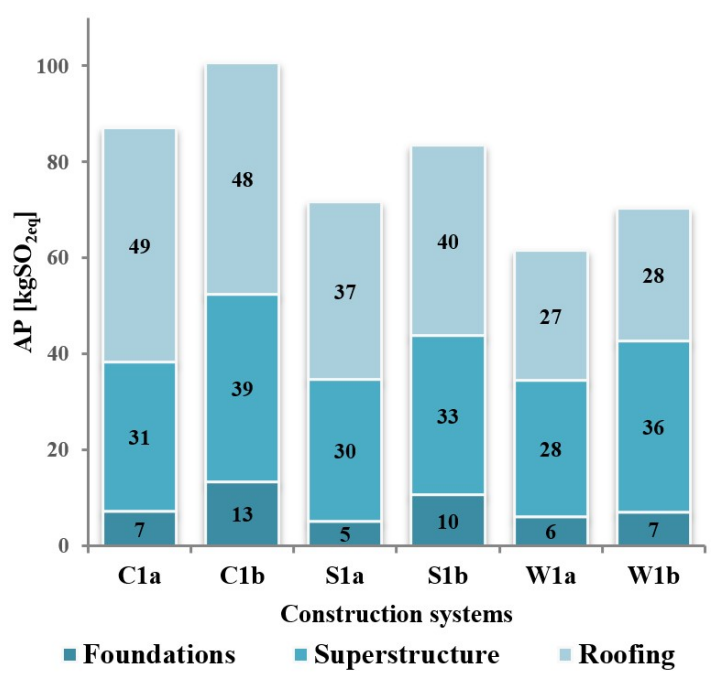

Figure 9. Module 1: Analysis of AP.

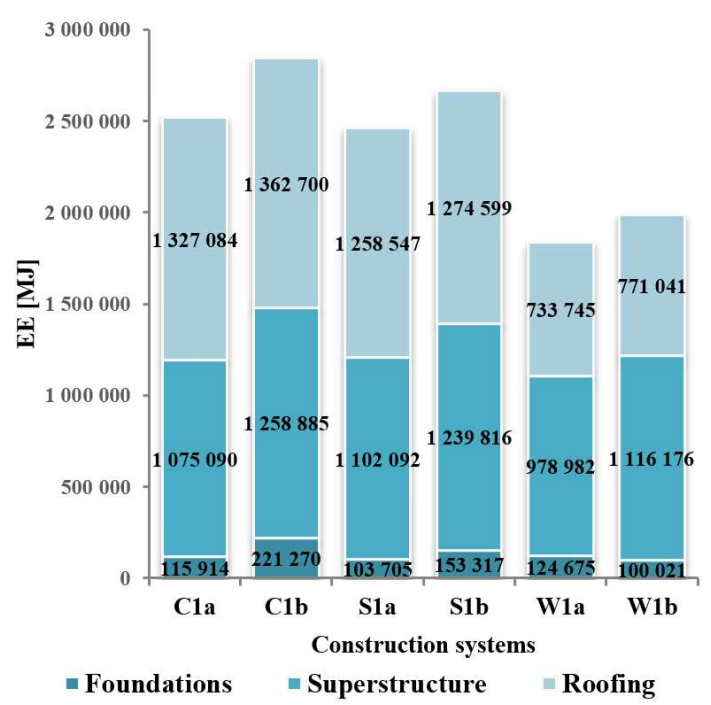

Figure 10. Whole construction: Analysis of EE. 


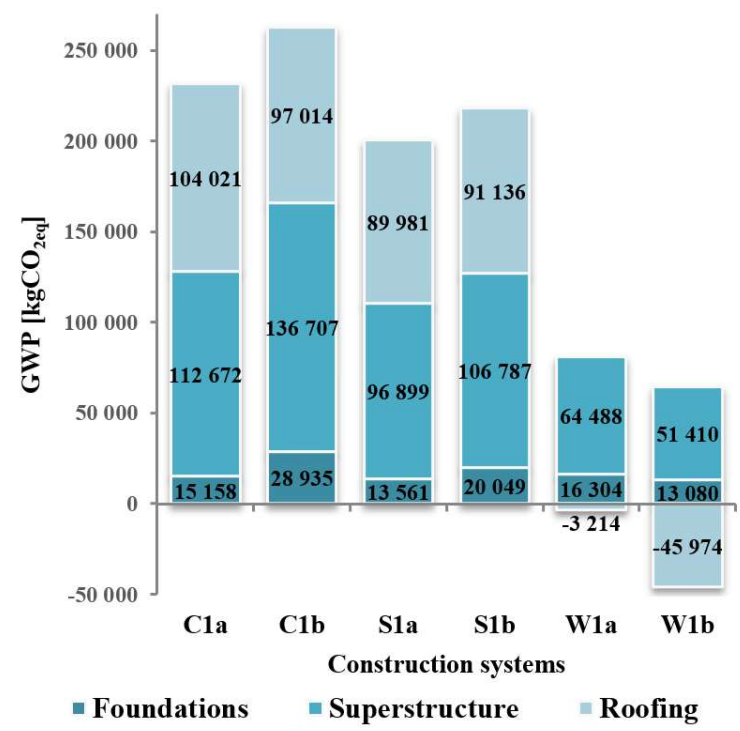

Figure 11. Whole construction: Analysis of GWP.

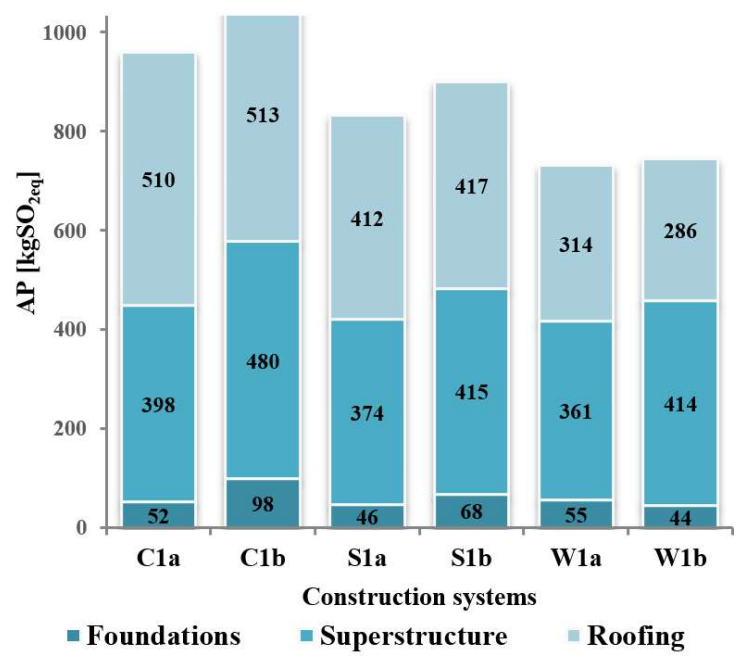

Figure 12. Whole construction: Analysis of AP.

Analysis of selected construction systems from the perspective of EE show comparable values between prefabricated concrete structures and steel construction systems (Figure 10). In the category of concrete-based construction systems, minor deviations in terms of foundation and superstructure were found for the $\mathrm{C} 1 \mathrm{~b}$ variant compared to $\mathrm{C} 1 \mathrm{a}(11.4 \%)$. This difference was caused mainly by the need for more massive columns in the construction system $\mathrm{C} 1 \mathrm{~b}$, which also involved the need for more massive foundations, which in the end resulted in higher parameters in terms of EE. Similar findings were also observed in the category of steel-based structural systems where the difference between the variants $\mathrm{S} 1 \mathrm{a}$ and $\mathrm{S} 1 \mathrm{~b}$ was $7.6 \%$. With these structural systems, deviations were also needed in the case of a more massive skeletal structure in the S1b system, with the need for more massive foundations. By comparing the $\mathrm{W} 1 \mathrm{a}$ and $\mathrm{W} 1 \mathrm{~b}$ wood construction variants, a $7.5 \%$ difference was observed in favor of the W1a design system. This difference can be attributed, in particular, to the use of more massive wood elements in the W1b system with a higher weight of the upper structure and the need for a more massive foundation structure.

Comparison of constructional systems in terms of material bases in the context of embodied energy (EE) showed a minimal mean difference (4.2\%) between concrete and steel construction systems. A significant difference was observed between steel and wood-based systems (25\%) and even timber-based construction systems had a significantly more favorable balance on average of $28.6 \%$ 
compared to concrete-based construction systems. This finding points to the considerable benefit of the use of wooden construction systems in terms of embodied energy.

In terms of GWP, similar differences between construction variants $\mathrm{C} 1 \mathrm{a}$ and $\mathrm{C} 1 \mathrm{~b}(11.7 \%)$ and between S1a and S1b (8\%) were observed for EE (Figure 11). A more significant difference was noted between the concrete-based construction systems and the steel-based systems (15.3\%). Significantly large difference was observed for systems based on wood compared to systems based on steel $(62.9-91.1 \%)$ and the difference between systems based on wood and concrete was $68.6-92.5 \%$. This significant difference is the result that the wood has a negative GWP balance, so its use is projected in this valuation parameter. In addition, the lower weight of the wood-based construction is seamlessly reflected in the need for smaller foundation structures compared to other concrete and steel options. A significant difference was also observed between $\mathrm{W} 1 \mathrm{a}$ and $\mathrm{W} 1 \mathrm{~b}$ timber systems (76\%). This was due to the fact that the W1a system is in practice designed and raised using an aluminum-based covering to increase the undesired balance of the whole building structure compared to the W1b construction where the multi-layer asphalt roofing was used. A more thoughtful and appropriate design in terms of the unsuitable balance of the materials used would achieve a more acceptable value of the resulting structure.

The assessment of construction systems in terms of AP points to $15.5-28 \%$ differences between wood-based constructions systems compared with steel and concrete-based systems (Figure 12). This observed difference was not as meaningful as in the previous parameters, attributable, in particular, to the use of glued wood-based and OSB boards in wood-based system variants. Since the production of glued structural elements based on wood and OSB boards is technologically demanding and contributes significantly to emission generation, ultimately, the wood-based materials mentioned above have a better balance in terms of environmental parameters than concrete, steel and aluminum materials. Improved wood recovery as such could be achieved by reducing and streamlining the entire production process of the production of wood-based components and in combination with materials that are effective in terms of the necessary requirements with a reasonable environmental impact.

In the category of concrete systems, a $12 \%$ difference between $\mathrm{C} 1 \mathrm{a}$ and $\mathrm{C} 1 \mathrm{~b}$ was observed. This difference can be attributed to the more massive base structures at C1a and also to the more massive skeletal structure of the upper structure. In the category of steel-based systems, a lower difference between S1a and S1b (7.5\%) was observed. Minimal differences were caused, similarly the concrete-based systems, with more massive foundation structures and a more massive construction of the S1b skeleton compared to S1a. In terms of AP, the minimum differences in the category of wood-based systems was observed between $\mathrm{W} 1 \mathrm{a}$ and $\mathrm{W} 1 \mathrm{~b}(1.8 \%)$.

Environmental benefits of modern prefab wooden building compared with the heavy prefabricated reinforced concrete and steel structure also lies in considerably lower weight structures, affecting both the overall load as well as the intensity of transport. In the case of the transport of materials, a significantly higher number of rigs was observed during the transport of materials in the absence of concrete-based systems compared to other comparable systems. These aspects are closely related to the amount of emissions produced, calculated according to Scheme 6. From the point of view of technological stages in the category of concrete-based systems, the basic stage of the superstructure was followed by the roofing phase and the base phase was involved in the production of $\mathrm{CO}_{2}$ emission throughout the transport of materials from production to the lowest stagnation rate (Table 2). Steel- and wood-based systems were comparable in the production of $\mathrm{CO}_{2}$ emissions in the transport of materials from production to construction in terms of technological stages. However, the production of $\mathrm{CO}_{2}$ emissions when transporting the materials needed for the roofing was significantly lower than at the start-up stage followed by the superstructure stage. 
Table 2. Analysis of emissions.

\begin{tabular}{|c|c|c|c|c|c|c|c|c|c|c|c|c|}
\hline & \multicolumn{4}{|c|}{ Range 20 km } & \multicolumn{4}{|c|}{ Range 50 km } & \multicolumn{4}{|c|}{ Range 100 km } \\
\hline$\stackrel{0}{\stackrel{2}{2}}$ & 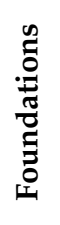 & 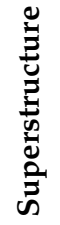 & 車 & $\underset{\Xi}{\Xi}$ & 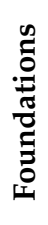 & 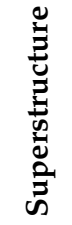 & 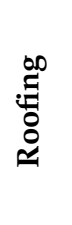 & ڤే & 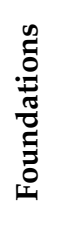 & 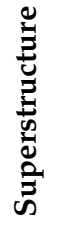 & $\underset{\simeq}{\Xi}$ & $\underset{\Xi}{\Xi}$ \\
\hline
\end{tabular}

\begin{tabular}{ccccccccccccc}
\hline & \multicolumn{10}{c}{ Emissions $\mathbf{C O}_{\mathbf{2}}(\mathbf{k g})$} \\
\hline C1a & 79 & 735 & 638 & $\mathbf{1 4 5 3}$ & 198 & 1838 & 1596 & $\mathbf{3 6 3 2}$ & 396 & 3676 & 3192 & $\mathbf{7 2 6 4}$ \\
\hline C1b & 151 & 861 & 631 & $\mathbf{1 6 4 3}$ & 378 & 2152 & 1577 & $\mathbf{4 1 0 8}$ & 756 & 4305 & 3154 & $\mathbf{8 2 1 5}$ \\
\hline S1a & 71 & 533 & 21 & $\mathbf{6 2 5}$ & 177 & 1333 & 54 & $\mathbf{1 5 6 4}$ & 355 & 2665 & 107 & $\mathbf{3 1 2 7}$ \\
\hline S1b & 105 & 536 & 22 & $\mathbf{6 6 3}$ & 262 & 1340 & 55 & $\mathbf{1 6 5 7}$ & 524 & 2680 & 109 & $\mathbf{3 3 1 4}$ \\
\hline W1a & 85 & 560 & 31 & $\mathbf{6 7 7}$ & 213 & 1401 & 79 & $\mathbf{1 6 9 3}$ & 426 & 2802 & 157 & $\mathbf{3 3 8 6}$ \\
\hline W1b & 68 & 580 & 46 & $\mathbf{6 9 5}$ & 171 & 1451 & 116 & $\mathbf{1 7 3 8}$ & 342 & 2902 & 231 & $\mathbf{3 4 7 5}$ \\
\hline
\end{tabular}

The analysis of selected construction systems in terms of $\mathrm{CO}_{2}$ emission production during the transportation of materials from construction to construction shows comparative values between steel-based structural systems and wood-based systems (Figure 13). In contrast to the construction system mentioned above, the concrete-based construction system has an undesirable balance of $\mathrm{CO}_{2}$ emission production during the transport of materials. Steel-based construction systems have a lower carbon dioxide emissions balance on average of $58.3 \%$ of materials compared to concrete-based systems. A similar finding was made by comparing wood-based systems and concrete-based systems where this balance is $55.6 \%$ in favor of wood-based systems. Such enormous undesirable values for concrete-based systems are based on a considerably heavier structure compared to the comparison system. Even when transporting $100 \mathrm{~km}$ of steel- and wood-based systems, $\mathrm{CO}_{2}$ emission emissions are lower than those used for conveying systems based on concrete at a distance of $50 \mathrm{~km}$.

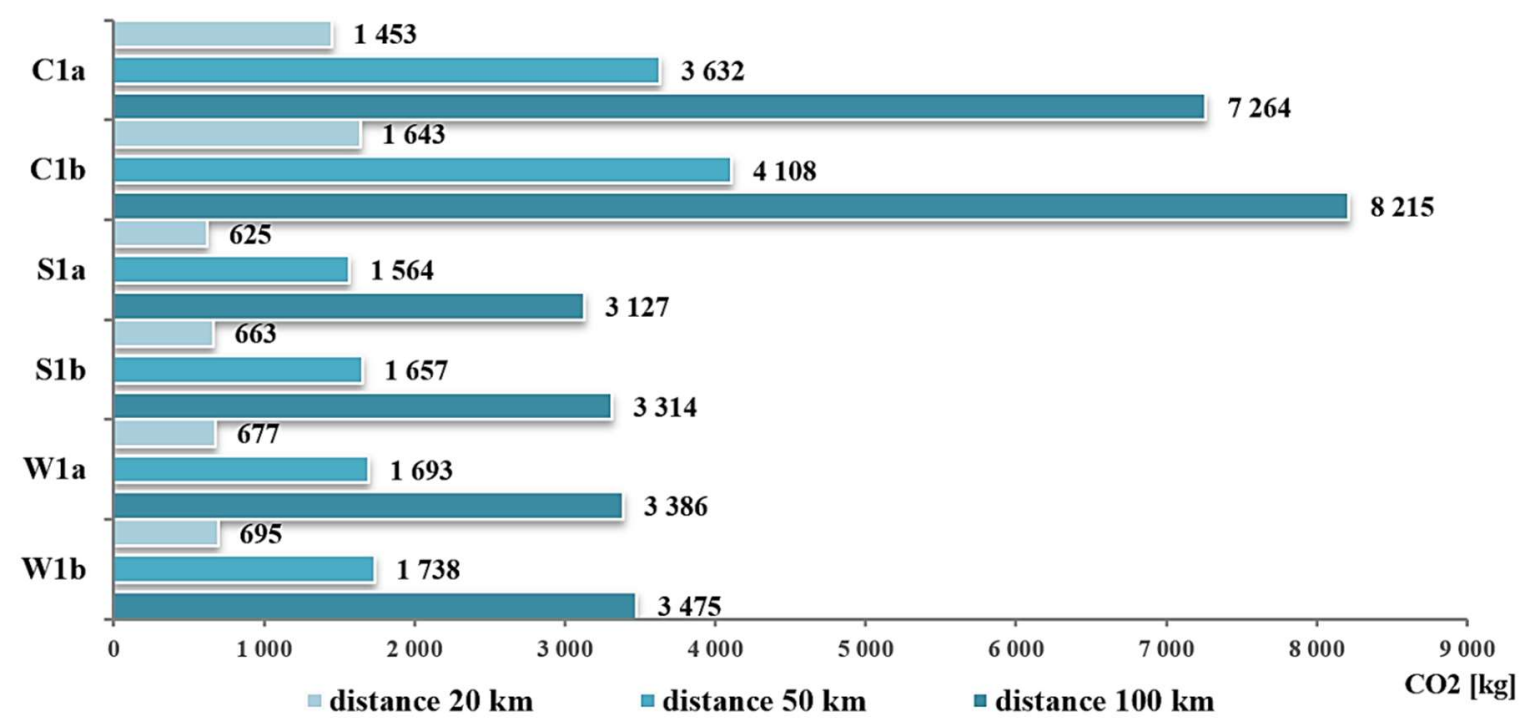

Figure 13. All construction: Analysis of emissions.

In the category of concrete-based construction systems, the difference between $\mathrm{Cla}$ and $\mathrm{C} 1 \mathrm{~b}$ was $11.5 \%$ at all three transport distances. The differences between these variants were due to a more massive skeleton and base in $\mathrm{C} 1 \mathrm{~b}$ variation over $\mathrm{C} 1 \mathrm{a}$. In the category of steel-based systems, the difference between S1a and S1b was only 5.6\%. With W1a and W1b wood-based systems, 
this difference was only $2.5 \%$. These findings suggest that the steel- and wood-based variants are not distributed in terms of weight and mass used as in the case of concrete-based systems.

\section{Discussion}

Hoxha et al. [33] focused on building research as we did in our analysis of LCA. They pointed out that the LCA evaluation method has its broad-spectrum use not only in the construction industry but in almost every industry sector. In their research, they focused on the analysis of several buildings, in particular in terms of the material base, and looked for the most significant differences between them. They concluded that the most beneficial effects on the environment in terms of LCA are derived from building materials such as steel, concrete and components. These arguments are also taught by our analysis. We determined the decisive impact on the overall environment is the production of the building materials and their subsequent use. Analyzing the impact of transport of used materials on the construction of evaluated systems, we can state that the impact of transport on the environment is not as significant as the production of building materials in terms of the assessed parameters. However, the impact of the transport of building materials cannot be omitted, because not only is a considerable amount of emissions produced during transport but also the transport itself affects the surrounding environment by its external influences. The mentioned authors also added the fact that the use of wood significantly affects the overall environmental footprint in a positive sense. We also found a positive balance of wood versus other materials in our study.

Takano et al. [34] and Martínez-Rocamora [35] similarly suggested that LCA analysis is a topical subject in the construction industry. These authors focused on the analysis of several wood-based buildings in the context of various selected material characteristics of environmental indicators. Subsequently, Takano et al. [34] found that the databases they were analyzing were not significantly different, but some differences were observed. In the context of our work and their work, there is a certain parallel in that wood and timber use in building systems is, according to the findings, beneficial from the point of view of the LCA. However, according to our findings as well as those of the mentioned authors, the environmental benefits of wood are indisputable, but the use of wood and wood-based elements is not always appropriate and possible, especially in terms of static and physical characteristics, depending on the type of use.

According to Soust-Verdaguer et al. [36], construction and its effects on the surrounding environment are constantly confronted with sustainability. Therefore, the authors mentioned that it is necessary to consider aspects of construction in relation to the surrounding environment. For such assessment, for example, LCA analysis is very useful and the more desirable for the evaluation of different variants. In our opinion, more or less detailed analyses are necessary if the construction industry is to be sustainable in the future. What is also evidenced by our present work is the impact of different variants of industrial agricultural construction in relation to the environment. The above-mentioned authors provided one important point that, based on LCA analyses, a number of sources can be saved in the future, both in energy production of building materials and energy in terms of the operation of construction sites. All of these aspects, in our opinion, ultimately reflect sustainability in this sector of construction.

Vilches et al. [37] and Häfliger et al. [38] pointed out that LCA assessment is a specific element in the design phase of construction projects. Therefore, these aspects need to be given due attention. Because of the deliberate and efficiently chosen composition of materials and design solutions, it is possible to achieve much better results in the resulting variant of investment projects. In addition, Häfliger et al. [38] identified, as we do in our work, that materials significantly contribute to the environmental impact and are particularly sensitive to the modeling of the resulting variants.

With the work of Cabeza et al. [39], our thoughts also stand out. They reported that most of the LCA study deals with the analysis of classical urban buildings or settlements, which divert views of the manufacturing sector or industrial buildings. Industrial buildings and structures with industrial character are represented in the construction sector by a large percentage, thus it is also necessary to 
deal with this area of construction. We also support these statements and therefore we have chosen to focus our present analysis on the impact of different agricultural construction options on the environment in terms of assessed LCA parameters within defined boundaries. Anand and Amor [40] added that, due to rapid development and progress in the building sector, LCA research across borders is very important, at both the material and component level, as well as at building and complex building systems. The above-mentioned assertion also coincides with our findings, based on our work, which suggests that a more effective resource management and a more sustainable construction sector can be achieved by appropriate analysis of the impact of construction on the environment.

The conclusions of our study show that the implementation of heavy reinforced concrete and steel structures reduces the sustainability of construction. On the other hand, the use of wood-based design solutions is once more effective with regard to the comparison of conventional concrete and steel systems, as well as in relation to production, implementation, and transport and its negative impact on the surrounding environment. Of course, it is not always possible to apply wood-based structures in terms of static or functional nature. However, a thoughtful and appropriate solution is to reduce the environmental footprint in the future while maintaining the desired functional requirements of the resulting construction or construction solution.

Nowadays, more environmentally friendly solutions such as wood-based structures are increasingly being launched. Finally, our work is also proof that the realization of wood-based buildings makes it possible to achieve more sustainable and efficient construction. Apart from classical buildings (family houses and administrative buildings), where woodworks are used to a greater extent than in the industrial sector, one of the big challenges is the larger implementation of wood-based buildings in industrial construction with its indisputable advantages in terms of sustainability and efficiency of construction process.

\section{Conclusions}

The results of this analysis, which compared assembled construction systems on different material bases for primary agricultural production, point to the benefits of modern wood-based construction systems compared to traditional materials (concrete and steel). The aforementioned benefits were manifested especially in the evaluated areas of environmental parameters embodied in energy, acidification potential and, especially, global warming potential. The percentage difference of global warming potential was significantly high for steel-based systems compared to wood-based construction systems (62.9-91.1\%), and the difference between the wood and concrete systems ranged from $68.6 \%$ to $92.5 \%$. From the point of view of the generation of $\mathrm{CO}_{2}$ emission throughout the transport of materials and components, the benefits of steel- and wood-based systems have been demonstrated over the iron-concrete systems, mostly due to a significantly higher weight of the transported materials and elements necessary for the construction of the iron-concrete systems. Thus, we conclude that, with a suitable combination of traditional and modern structural elements, we can achieve significantly more efficient constructions and structures with a more favorable environmental impact while maintaining the basic requirements of the bearing capacity, stability and the resulting function of the building itself. Cleaner and more environmentally friendly technologies are of great importance for sustainability. Therefore, this analysis and its findings can contribute to a better decision-making process within a more sustainable construction sector.

Author Contributions: J.Š., M.K. and T.P. conceived and designed the experiments; J.Š. and T.P. performed the experiments; J.Š. analyzed the data; J.Š. contributed reagents/materials/analysis tools; J. Š., M.K. and T.P. wrote the paper.

Funding: VEGA project-1/0557/18 "Research and development of process and product innovations of modern methods of construction in the context of the Industry 4.0 principles".

Acknowledgments: The article presents a partial research result of the VEGA project-1/0557/18 "Research and development of process and product innovations of modern methods of construction in the context of the Industry 4.0 principles". 
Conflicts of Interest: The authors declare no conflicts of interest.

\section{References}

1. Attia, S. Modern History of Sustainable Architecture. In Regenerative and Positive Impact Architecture; Springer: Cham, Switzerland, 2018.

2. Kishawy, H.A.; Hegab, H.; Saad, E. Design for Sustainable Manufacturing: Approach, Implementation, and Assessment. Sustainability 2018, 10, 3604. [CrossRef]

3. Kamali, M.; Hewage, K. Development of performance criteria for sustainability evaluation of modular versus conventional construction methods. J. Clean. Prod. 2017, 142, 3592-3606. [CrossRef]

4. Lin, K.W.; Shih, C.M. The comparative analysis of neighborhood sustainability assessment tool. Environ. Plan. B Urban Anal. City Sci. 2018, 45, 90-105. [CrossRef]

5. Food and Agriculture Organization of the United Nations. Building a Common Vision for Sustainable Food and Agriculture; Food and Agriculture Organization of the United Nations: Rome, Italy, 2014; ISBN 978-92-5-108471-7.

6. The Organisation for Economic Co-operation and Development (OECD). Measuring Aid to Agriculture. Available online: www.oecd.org/agriculture (accessed on 12 September 2018).

7. Moustafa, K. Food and Sustainability Challenges under Climate Changes. Sci. Eng. Ethics 2016, 22, 1831-1836. [CrossRef] [PubMed]

8. Arcari, P. Normalised, human-centric discourses of meat and animals in climate change, sustainability and food security literature. Agric. Hum. Values 2017, 34, 69-86. [CrossRef]

9. Veissier, I.; Butterworth, A.; Bock, B.; Roe, E. European approaches to ensure good animal welfare. Appl. Anim. Behav. Sci. 2008, 113, 279-297. [CrossRef]

10. Kimáková, T.; Kuzmová, L.; Nevolná, Z.; Bencko, V. Fish and fish products as risk factors of mercury exposure. Ann. Agric. Environ. Med. 2018, 25, 488-493. [CrossRef] [PubMed]

11. Langford, F.M.; Stott, A.W. Culled early or culled late: Economic decisions and risks to welfare in dairy cows. Anim. Welf. 2012, 21, 41-55. [CrossRef]

12. Koc, B.; Ceylan, M. The effects of social-economic status of consumers on purchasing, behaving and attitude to food products Case study of Van, Turkey. Br. Food J. 2012, 114, 728-742. [CrossRef]

13. Opp, C.; Ziebolz, B.; Groll, M. Ecological, socio-economic and demographic analyses as prerequisites for sewage treatment problem solutions in rural areas. The case study of Dirlammen, Vogelsberg, Germany. ERDE 2018, 149, 184-197. [CrossRef]

14. Sanye-Mengual, E.; Orsini, F.; Gianquinto, G. Revisiting the Sustainability Concept of Urban Food Production from a Stakeholders' Perspective. Sustainability 2018, 10, 2175. [CrossRef]

15. Stevens, J.R.; Newton, R.W.; Tlusty, M.; Little, D.C. The rise of aquaculture by-products: Increasing food production, value, and sustainability through strategic utilisation. Mar. Policy 2018, 90, 115-124. [CrossRef]

16. Drozd, W.; Leśniak, A. Ecological Wall Systems as an Element of Sustainable Development-Cost Issues. Sustainability 2018, 10, 2234. [CrossRef]

17. Zima, K. Index Cost Estimate Based BIM Method-Computational Example for Sports Fields. In Proceedings of the International Conference on Numerical Analysis and Applied Mathematics (ICNAAM-2016), Rhodes, Greece, 19-25 September 2016; Volume 1863. [CrossRef]

18. Hong, J.; Shen, G.Q.; Li, Z.; Zhang, B.; Zhang, W. Barriers to promoting prefabricated construction in China: A costebenefit analysis. J. Clean. Prod. 2018, 172, 649-660. [CrossRef]

19. Kristjansdottir, T.F.; Houlihan-Wiberg, A.; Andresen, I.; Georges, L.; Heeren, N.; Good, C.S.; Brattebø, H. Is a net life cycle balance for energy and materials achievable for a zero emission single-family building in Norway? Energy Build. 2018, 168, 457-469. [CrossRef]

20. Filho, W.L.; Pociovălișteanu, D.M.; Borges de Brito, P.R.; Borges de Lima, I. Towards a Sustainable Bioeconomy: Principles, Challenges and Perspectives; Springer: Cham, Switzerland, 2018.

21. Do, H.; Cetin, K.S. Evaluation of the causes and impact of outliers on residential building energy use prediction using inverse modeling. Build. Environ. 2018, 138, 194-206. [CrossRef]

22. Ďubek, M.; Makýš, P.; Ďubek, S.; Hajduchová, S.; Petro, M. The Evaluation of the Content of Fibers in Steel Fiber Reinforced Structures and Image Analysis. J. Civ. Eng. Manag. 2018, 24, 183-192. [CrossRef] 
23. Antošová, N.; Ďubek, M.; Petro, M. Verification of the technology choice repairs ETICS. In Advances and Trends in Engineering Sciences and Technologies II: Proceedings of the 2nd International Conference on Engineering Sciences and Technologies. High Tatras Mountains, Tatranské Matliare, Slovak Republic, 29 June-1 July 2016. 1. vyd; Taylor \& Francis Group: London, UK, 2017; pp. 323-328, ISBN 978-1-138-03224-8.

24. Invidiata, A.; Lavagna, M.; Ghisia, E. Selecting design strategies using multi-criteria decision making to improve the sustainability of buildings. Build. Environ. 2018, 139, 58-68. [CrossRef]

25. Kamali, M.; Hewage, K. Life cycle performance of modular buildings: A critical review. Renew. Sustain. Energy Rev. 2016, 62, 1171-1183. [CrossRef]

26. Tulevech, S.M.; Hage, D.J.; Jorgensen, S.K.; Guensler, C.L.; Himmler, R.; Gheewala, S.H. Life cycle assessment: A multi-scenario case study of a low-energy industrial building in Thailand. Energy Build. 2018, 168, 191-200. [CrossRef]

27. Kamali, M.; Hewage, K.; Milani, A.S. Life cycle sustainability performance assessment framework for residential modular buildings: Aggregated sustainability indices. Build. Environ. 2018, 138, 21-41. [CrossRef]

28. Østergaard, N.; Thorsted, L.; Miraglia, S.; Birkved, M.; Rasmussen, F.N.; Birgisdóttir, H.; Kalbar, P.; Georgiadis, S. Data driven quantification of the temporal scope of building LCAs. Procedia CIRP 2018, 69, 224-229. [CrossRef]

29. Lu, H.R.; Hanandeh, A.E.; Gilbert, B.; Bailleres, H. A comparative life cycle assessment (LCA) of alternative material for Australian building construction. MATEC Web Conf. 2017, 120, 02013. [CrossRef]

30. Marique, A.-F.; Rossi, B. Cradle-to-grave life-cycle assessment within the built environment: Comparison between the refurbishment and the complete reconstruction of an office building in Belgium. J. Environ. Manag. 2018, 224, 396-405. [CrossRef] [PubMed]

31. Sýkora, J.; Košatka, B.; Daneš, K. Hospodářske Stavby; ARCH: Praha, Czech Republic, 1992.

32. IBO Passivhaus-Bauteilkatalog. Austrian Institute for Baubiologie and Ecology. Available online: http:/ / www.ibo.at/en/ (accessed on 12 September 2018).

33. Hoxha, E.; Habert, G.; Lasvaux, S.; Chevalier, J.; Le Roy, R. Influence of construction material uncertainties on residential building LCA reliability. J. Clean. Prod. 2017, 144, 33-47. [CrossRef]

34. Takano, A.; Winter, S.; Hughes, M.; Linkosalmi, L. Comparison of life cycle assessment databases: A case study on building assessment. Build. Environ. 2014, 79, 20-30. [CrossRef]

35. Martínez-Rocamora, A.; Solís-Guzmán, J.; Marrero, M. LCA databases focused on construction materials: A review. Renew. Sustain. Energy Rev. 2016, 58, 565-573. [CrossRef]

36. Soust-Verdaguer, B.; Llatas, C.; García-Martínez, G. Critical review of bim-based LCA method to buildings. Energy Build. 2017, 136, 110-120. [CrossRef]

37. Vilches, A.; Garcia-Martinez, A.; Sanchez-Montaňes, B. Life cycle assessment (LCA) of building refurbishment: A literature review. Energy Build. 2017, 135, 286-301. [CrossRef]

38. Häfliger, I.F.; John, V.; Passer, A.; Lasvaux, S.; Hoxha, E.; Saade, M.R.M.; Habert, G. Buildings environmental impacts' sensitivity related to LCA modelling choices of construction materials. J. Clean. Prod. 2017, 156, 805-816. [CrossRef]

39. Cabeza, L.F.; Rincón, L.; Vilariño, V.; Pérez, G.; Castell, A. Life cycle assessment (LCA) and life cycle energy analysis (LCEA) of buildings and the building sector: A review. Renew. Sustain. Energy Rev. 2014, 29, 394-416. [CrossRef]

40. Anand, C.K.; Amor, B. Recent developments, future challenges and new research directions in LCA of buildings: A critical review. Renew. Sustain. Energy Rev. 2017, 67, 408-416. [CrossRef]

(C) 2018 by the authors. Licensee MDPI, Basel, Switzerland. This article is an open access article distributed under the terms and conditions of the Creative Commons Attribution (CC BY) license (http://creativecommons.org/licenses/by/4.0/). 